\title{
Train as a Math Teacher: Creative and Proactive Process of Pro- fessional Development
}

\author{
José Villella* $^{\circledR}$, Gema Fioriti, Rosa Ferragina ${ }^{\circledR}$, Fernando Bifano ${ }^{\circledR}$, Leonardo Lupinacci ${ }^{\circledR}$, Alejandra \\ Almirón ${ }^{\circledR}$, Victoria Güerci ${ }^{\circledR}$, Susana Ammann
}

Center for Studies in Specific Didactics. Research Laboratory in Human Sciences. National University of San Martín-National Council for Scientific and Technical Research. Buenos Aires. Argentina

Email: cede@unsam.edu.ar

Received: 24 April 2021; Revised: 16 July 2021; Accepted: 19 July 2021

\begin{abstract}
In this article we share a study on a professional development training program for math teachers. It is presented as innovative as it focuses on the reflection on the practice of teaching through the raising and solution of professional problems. We define professional problems, such as those teaching situations to which the teacher seeks solutions. We demonstrate with excerpts from working sessions that these solutions are nourished by the reflection on the practice they are trying to modify. They are, as a whole, indicators of specialized knowledge that characterize a professional of teaching mathematics.
\end{abstract}

Keywords: specialized knowledge, didactics of mathematics, professional teacher development

\section{Introduction}

Continuing teacher training has received, over time, different denominations: improvement, continuous training, updating, retraining, in-service training, professional development (Vezub, 2019). The choice of one of these terms refers to traits of identity and professional profile, of the conception of teaching work, of the type of knowledge, skills that teachers are expected to perform in the educational system and in society. Various documents (OECD, 2005; OREALC, 2013), manifest the need to strengthen the preparation of teachers so that they can face the current challenges of the schooling of children, adolescents, youth and adults, and improve learning, school social climates (Anderson, 1970) and educational quality. The experience we share, takes into account this need and shows a way to satisfy it from the dialogue that is established between the didactics of mathematics, the results of its research and the practice of teaching. This experience is an example of professional development, a name we choose since it provides a broad, articulated and integrated vision of teacher learning throughout its history and is consistent with the conception of teacher training as a long-term process (Bullough, 2000; Cochran \& Lytke, 2003), which integrates both initial and continuing education (Avalos, 2007).

We consider the need to offer professionals in the teaching of mathematics, study spaces in which they can rethink their practices to enrich them and adapt them to the needs of the groups of students with whom they work daily, promoting coherence between conceptions and classroom practice (Kaiser \& Li, 2011), improving reflective ability

Copyright (C2021 José Villella, et al.

DOI: https://doi.org/10.37256/ser.222021894

This is an open-access article distributed under a CC BY license

(Creative Commons Attribution 4.0 International License)

https://creativecommons.org/licenses/by/4.0/ 
(Cobb \& McLain, 2001), and increasing professional knowledge (Bell et al., 2010). In agreement with Artigue (2004), we qualify this experience as a creative process that generates spaces for discussion about the problems that teaching involves. It constitutes a personal and contextualized space in the classrooms, since what is developed in it, watering in the research in didactics of mathematics to stress the naive and tempting solutions to the complex problems that arise in the classes. At the same time, it is a proactive process because, from the reflection on practice, synergies that allow the incidence of mathematics didactics can be established, to both train teachers and teaching professionals and guide their practice in the classroom (Lin \& Rowland, 2016).

The experience we report takes the form of a Diploma that we share as an object of study of a research program [We refer to an investigation project from the Center for Studies in Specific Didactics (CEDE, for its acronym in Spanish), member of the Research Laboratory in Human Sciences (LICH, for its acronym in Spanish) from the National University of San Martín (UNSAM, for its acronym in Spanish) and the National Council for Scientific and Technical Research (CONICET, for its acronym in Spanish) in Buenos Aires, Argentina.], which offers a section of professional teacher development, aimed at generating professional knowledge in the field of mathematics education [In Argentina where this Diploma is carried out, the teaching training for early childhood education takes place mostly in Higher Institutes of Teacher Training (ISFD, for its acronym in Argentina), through study plans that last four years. Some provinces in this country also offer this training in universities]. In Argentina, teachers in the exercise of their profession are offered stages of elective continuous training, focused on a professional topic or disciplinary content of an average duration of 64 hours. This Diploma stands out among these proposals for continuous training because:

- it focuses on the updating and specialization within the disciplinary field of mathematics didactics;

- it is offered in the university context;

- it is taken in the distance modality;

- it is organized in training spaces that work on the problems of teaching mathematics in school; the selection and use of various teaching materials; the reading, interpretation and evaluation of the productions of the students; the organization of classrooms as environments in which a group of people construct mathematical knowledge;

- it is organized in curricular spaces that take two semesters, which gives continuity and progression to the topics on which it works;

- it offers a space for federal training (between teachers from different jurisdictions) and international training (with teachers from other Spanish-speaking countries).

As a whole, this product for professional development, is presented as a space designed in relation to institutional cultures, teaching working conditions, the coherence and clarity of the mathematics curriculum: hence its novelty that stresses the range of short-term thematic courses, with which the national training policy (this is the case of Argentina and several of the countries of the Iberic-American region) tries to train its teachers (Vezub, 2018).

In the theoretical basis of this experience, we assume the teaching of mathematics as a social practice that responds to needs that exceed the teaching intentions and finds its meaning in the characteristics of society and culture, in a specific time and space, in which it develops (Cobb et al., 2016; Rhoads et al., 2011; Skovsmose, 1999; Villella et al., 2018a). In addition, this teaching of mathematics is a process that is built on social interaction, in which those who participate share the appropriate linguistic discourses and terms, the type of activities and processes involved, the roles and rules that apply to the interactions, as well as the objectives of the institution in which this practice is carried out.

\section{Theoretical framework}

Mathematical knowledge, as well as knowledge in general, has changed its nature and its role in society, which has led to the need to modify our relationship with it: we have gone from a relationship of dominance-typical of the twentieth century to another of management and competent use of this knowledge in the twenty-first century. In this century, the accumulation of disciplinary knowledge is not considered as a positive quality of a citizen, but it prioritizes what to do with these contents in the diary of events. This fact has caused a change in our conceptions about training, teaching, and evaluation that leads us to consider: what types of knowledge and skills are those that allow teachers to teach mathematics in a way compatible with the education reform project; what kind of experiences constitute genuine activities with regard to these learnings and what contexts are most appropriate to place these activities (Putman \& Borko, 2000). 
So, positioning ourselves from a professional teaching role to think about what happens when we teach mathematics implies:

- we have to think about teachers and their practices destined to somebody else with whom they establish a teaching and learning relationship;

- the mathematical content circulating in the classroom makes sense in a social framework and a moment and historical process: it produces particular experiences and specific actions;

- among teachers and students, and the mediation of the circulating content, social construction is made that parts from individualities to become a cultural "us";

- mathematical learning is not something that comes naturally from the predisposition of listening: many factors may hinder it and others that help it. It requires a scenario built ad hoc, a didactic scenario that generates a learning situation;

- didactic interventions determine learning (Vezub, 2013; 2019; Villella et al., 2018a).

From this description of the dynamics inside the classroom, a professional interpellation about the teacher's role emerges; the decision related to what we teach in mathematics and how we do it involves the consideration of what becomes relevant, meaningful, and valuable about the content and the learning process. Likewise, determining what to prioritize during the teaching process is related to our knowledge about learning, about how it is produced, which are its regularities, qualities, and conditions in the context of the classroom scenario. Therefore, it is necessary to design a homogeneous theoretical-methodological framework to develop in teachers the knowledge of the content and its didactics $(\mathrm{Wu}, 2018)$ that manifests itself through professional competences to plan teaching situations, through which to achieve that the students who learn mathematics in school institutions acquire a thorough knowledge of school mathematics to whose conceptual network belong the contents that give meaning and significance to the teaching sequences that circulate in the classroom:

- master a repertoire of heuristic techniques and strategies broad enough to be able to solve situations of different formats and origins;

- regulate the resolution process regarding the application of the contents that they consider relevant to that network we talked about, and the strategies that they assume are the most appropriate.

In this way, teachers put their specific knowledge regarding mathematics at the service of their student's learning. This professional expertise of those who teach mathematics can be synthesized in the following aspects:

- they answer with a mathematical background, to the questions asked by their students;

- they propose different ways to analyze a mathematical concept, which allows the person studying it to understand the conceptual network related to this concept;

- they recognize what is being signified from an epistemological and conceptual point of view through the use of representations selected ad hoc for that class;

- they establish relations between what they taught in the past and what they'll teach in the future;

- they arrange didactic variables for the tasks they propose;

- they evaluate the mathematical validity of their student's affirmations;

- they create problems that enable the production of mathematical knowledge in their students (Ball et al., 2008; 2009).

In this way, we think of teachers as professionals in the teaching of mathematics who own useful knowledge (Rowland \& Turner, 2009). This useful knowledge is displayed through mastery of the content to be taught, and the didactics of mathematics that supports the organization of your class and your beliefs about what mathematics is and how it should be learned. Moreover, this personal teaching knowledge gives them the expertise to design how the curricular prescribed content can be adapted, transposed according to the group and, how these contents integrate themselves in an intra and extra mathematical conceptual network that fluctuates between different fields, according to the possibilities and needs of the group they are working with.

This Diploma is a space of professional development in which we maintain that the teacher needs to know mathematics in different ways, as well as the different interactions that both students may have with herself or himself with mathematics during the development of a class. A space in which relevant problems for classroom practice can be developed, from an interventionist look towards the class being analyzed, supported by theoretical references and with a pragmatic orientation that involves reviewing and/or abandoning conjectures in search of a certain generality (Cobb 
et al., 2016).We understand that the Diploma must be organized in a corpus of curricular spaces that offer a renewed look at the teaching and learning processes of mathematics, attending to the analysis of the practices and mathematical knowledge that are shown in permanent evolution and progress. It is based on the approach of professional tasks whose nature is based on situations related to practice and theoretically guided by the results of research. It takes into consideration in the design of these tasks: a theoretical reference, a logic of development during the teaching process and the study of a mathematical content from research (Aké \& López-Mojica, 2020).

Some investigations that have as object of study the teacher as those that are based on a professional look (Sánchez-Matamoros et al., 2015); in professional knowledge (Montes et al., 2013; Carrillo et al., 2018), professional identity (Sanhueza et al., 2013) and teacher empowerment (Reyes-Gasperini \& Cantoral, 2013), among others, provide a framework for thinking about a certain parallelism between this possibility of professional development and initial training. Other research (Carrillo \& Climent, 2011; Rhoads et al., 2011; Carrillo et al., 2020), allow to think of the initial and continuous training, as a coherent and consistent training continuum, where reflection has a central role. It is in this complementary dialogue of options, in which the idea of the existence of models of professional knowledge, allows us to consider them as structuring the organization of this Diploma (Carrillo et al., 2013; 2020).

In this space of professional development, we will then assume that knowledge can be associated with the idea of specialized teaching knowledge (Villella et al., 2018a).

It is the knowledge formed by:

- the conceptual network of the mathematics that is taught: from its structure to its social projection and its scientific use;

- how the mathematical knowledge is produced and how the teacher can produce it referring to the concepts they will develop in the classroom;

- the knowledge related to the didactic of mathematics: how mathematics is learned and how it should be taught.

\subsection{The specialized knowledge of the mathematics teacher}

Those teachers who teach mathematics are assumed as teaching professionals when among other qualities, they consider that the process of problem resolution that students face, produces as a result of the construction of mathematical knowledge locally adapted. This knowledge generates a conflict between the subjectivity of students and teachers that are reformulated from diverse scopes, linked to the social scene. In this way, the reflection about the professional practice called teaching is not only referred to the study of what teachers do when they manage a class or when they design it but also the moments in which they interact with the mathematical content they choose and prioritize to give sustenance to the sequences they prepare for the class (Villella et al., 2018b). These interactions are taken into account concerning different kinds of knowledge; the relation between experiential knowledge and theory; the speech; knowledge about what to teach, what for, and how; the knowledge about teaching strategies, among others. This professional knowledge allows teachers to "look meaningfully" (Mason, 2002), so they can identify problems about practice (questions that will help them build provisional answers) related to teaching for mathematics learning.

The professional knowledge of those who teach mathematics is assumed as a way of understanding the mathematical contents prescribed in the curriculum, linked to the understanding of how they are learned and, therefore, how they can be taught. Thus, this knowledge acquires a specialized character (in the sense attributed in the model of the Mathematics Teacher's Specialized Knowledge (MTSK)). This model follows the structure proposed by Shulman (1986), establishing two domains of knowledge: disciplinary knowledge (in our case mathematics), and didactic knowledge of the content. The MTSK knowledge model also encompasses the teacher's beliefs about mathematics and its teaching and learning. Mathematical Knowledge (MK) comprises the mathematical knowledge possessed by the teachers. This knowledge allows them to plan, manage and reflect on teaching situations. In the MTSK model, this knowledge comprises three subdomains: knowledge of the topics that develop in the teaching situation; knowledge of the mathematical structure or knowledge of how the topic developed in the class relates to other topics or mathematical concepts; knowledge of mathematical practice or knowledge of the syntax of mathematics that gives an account of what the teacher knows about the mathematical work underlying the proposed mathematical activity.

Didactic knowledge of content or Pedagogical Content Knowledge (PCK) encompasses the knowledge that the teacher possesses about the teaching and learning of a particular content. The MTSK model proposes three subdomains related to the PCK: the Knowledge of Mathematics Teaching, which refers to teaching knowledge about how to adapt 
the mathematical content to make it understandable to students and takes into consideration the theories on the teaching of mathematics, which allow it to organize its practices as well as the selection and use of the resources it chooses for it; the Knowledge of the Characteristics of the Learning of Mathematics, which encompasses the knowledge that the teacher possesses about how the mathematical content is learned; the Knowledge of Mathematics Learning Standards, which takes into account how much the teacher knows about what should be learned at each moment of schooling. On the basis of this description, we affirm that there is a difference between the mathematical knowledge that the teacher needs (specialized knowledge of the content) and that needed by another user of mathematics (advanced or superficial common knowledge that does not need to be taught). Specialization, therefore, refers to the task of teaching-it takes into account the relationships between the contents themselves, and relations with other contents of other subjects-not to the advanced mathematical knowledge needed. This knowledge is complex, as it requires a deep understanding of the mathematical content of the ability to connect one topic with another, taking into account its epistemological warp and its historical appearance (Ma, 1999). Professional teaching knowledge is specialized, contextualized, integrated and complex, practical, dynamic, and partially tacit (Climent, 2005), social and critical. Professional knowledge is personal, as long as it is proper to each teacher and different from any other and it depends on their conceptions, values, attitudes, and experience (vital and/or professional). It's a contextualized knowledge because it's generated concerning professional contexts. It's integrated and complex because it holds learning from different nature (scientific, didactic, psychological, sociological, etc.). Teacher's knowledge is practical, it is a knowledge for practice that grows from it, too. It makes sense in the action accompanied by the theoretical reflection that allows transforming knowledge from action into theory from the action (partially tacit knowledge). Likewise, it is a dynamic knowledge, in constant evolution that grows through the interaction with students, and professional and personal experiences. It is built on work communities (social), collaboratively and it allows us to produce founded, critical knowledge about teaching.

\subsection{A diploma as an academic structure for the professional development of mathematics teachers: a possible teaching experiment}

We propose a section of professional training technically called Diploma that, assuming its students as teachers in the exercise of their profession, takes the domains of the MTSK as an object of study. To this end, we based the proposal on the idea of professional problems analyzed through which we could consider teaching experiments (Steffe \& Thompson, 2000; Molina et al., 2011) for the professional development of the teachers involved in it (Cobb et al., 2016). The objective of the Diploma is that the participating teachers reflect on the teaching and learning of mathematics, which they must know when they decide to bring a problem to the classroom.

We believe that to promote the development of the student's mathematical work, we must question this work from the perspective of the school organization by the teacher. This involves analyzing the student's performance in the classroom, the role of the resources on the transformation of workspaces, the study of the meaning of the knowledge given through the selected resources, and social and institutional aspects that interfere in this space (Kuzniak, 2011). When we think about mathematical activity in the classroom, genuinely represented by problem resolution, we do it concerning the elaboration of workspaces that allow the full involvement of students in the resolution and the teacher in their guidance and supervision. To do so, we consider it necessary to take into account: the epistemological conception that the teacher has about mathematics; the election and organization of the sequences of activities proposed to the students; the didactic analysis of the task set developed by the group of students as a possible solution to those sequences and the substantiation they make on them. This classroom conception allows the teacher to assume that mathematics takes place in a particular social context with young people who will become citizens of a particular society, not of another. The teacher's role is related to the organization of each student's interaction with the object of knowledge, whose task is conceived as a mediation, so the whole activity to be carried out results meaningful and stimulates the development potential of each student in cooperative group work: between students and between teachers and students. In this way, teachers conceive and activate the functional value of cultural learning in the daily life of each student. By doing so, teachers will be able to reproduce a traditional culture, generate contradictions and promote alternatives; to facilitate the integration of different training possibilities inside and outside the classroom to their students; to design and organize disciplinary and interdisciplinary work; to collaborate with the world outside the school, making the educational experience an individual and, at the same time, socializing experience. The teacher is not 
an undisputed authority that always has the right answers. These must be sought, contrasted, and verified in the group in the framework of the dynamics of a learning community. The mechanical search for solutions to the pedagogical problems is replaced by the invention and resolution of problems as open situations, in which all of the information is not always available or there's more than needed, where the solution doesn't always exist or is not unique and where "the other one" appears as an unavoidable figure for collaborative learning, that without ceasing to be an eminently individual act, it becomes a social activity in which debate and share ideas, suggestions and proposals prevail. The curricular prescribed mathematical ideas can be considered powerful (Skovsmose, 1999) when studied from different frameworks:

- From a perspective based on disciplinary logic: Some mathematical ideas grant us to establish relationships among the theories and provide new meanings to previously defined concepts, as it is documented in mathematics history. The power of these ideas is an intrinsic and essential characteristic of its position in the conceptual network that vertebrate mathematics. These ideas interpretation somehow legitimates the existence of an abstract curriculum that shutters the possibility of participating in a meaningful experience in mathematics learning for a great number of students.

- From the sociocultural perspective of the learner: Some mathematical ideas can be analyzed based on the relation of the student experience-the sense of the mathematic to study. The central thing in this vision is the analysis of the learning potential of mathematics: it is significant what students can capture and what they can give meaning to during the process of development of mathematical thinking. It is about connecting powerful mathematical ideas to the opportunity's students have to participate in social practices: related to what they interpret and conceptualize as their future life conditions considering the social, cultural, economic, and political environment in which they live.

- From a sociological perspective: Mathematical ideas can be defined as a resource to the action in society because mathematics doesn't exist as an independent knowledge in society. Social actors use mathematics as a descriptive and prescriptive instrument: its contents are a part of the available resources for planning and decision making.

Teaching situations are problematic situations characterized by uncertainty, disorder, and indeterminacy. During its development, students are shown as different from each other from the possibility that is offered to them to: chose their own resolution path; reflect on the elections they make to solve them, and enjoy a certain degree of freedom in knowledge building. These are dynamic situations and they assume the form of complex systems made up of different problems that interact among themselves that become the object with which we work in the teaching experiment that we call Diploma and that proposes to provide the group of students with skills to:

- Lead teaching processes that produce meaningful learning in mathematics;

- Integrate work teams for the elaboration of institutional curricular projects;

- Elaborate, guide and advise about the selection and use of resources for mathematics teaching;

- Participate in educational innovation projects related to mathematics;

- Participate in interdisciplinary teams for didactic research;

- Participate in the elaboration and evaluation of: curricular designs, resources for mathematics teaching, and didactic strategies to create teaching sequences and investigation projects related to didactic of mathematics;

- Counsel on everything related to the problems of mathematics teaching.

\section{The teaching experiment: diploma of higher studies in mathematics teaching}

In general, teaching experiments, in particular, those focused on professional development, usually have three phases (Cobb et al., 2016):

- Preparation: collects the starting points of teachers regarding the variables to be analyzed to outline a planned trajectory of professional learning;

- Experimentation: collects data that make possible a subsequent analysis;

- A retrospective analysis: it consists of studying whether the components of the previously assumed professional learning trajectory were reached, looking for generalizations, based on the theoretical elements that support the experiment.

In this Diploma, of virtual course, the phases are adapted to the proposal of work and are described as follows. 


\subsection{The experiment data}

The Diploma is an academic instance of university training, which does not grant a bachelor's degree, but professional recognition of the different jurisdictions in which it is taught. The one we share in this article is organized into three seminars and a workshop of a duration of 64 clock hours each. Seminars are academic instances of study of problems relevant to vocational training. They include the critical reflection of previous conceptions or assumptions about such problems, which teachers have incorporated as a result of their own practice, and then deepen their understanding through reading and debate of bibliographic or research materials. These seminars allow the questioning of "practical thinking" and exercise in reflective work and in the management of specific literature, as active users of the production of knowledge. The workshops are aimed at the development of competencies oriented to the instrumentation required for professional action and the practical resolution of situations, understanding the practice not only as the doing, but as the creative and reflective doing, putting into play all the available conceptual frameworks. The workshop aims at the development of capacities for the analysis of cases and alternatives for action, decision-making and the production of solutions and innovations to address them. They are offered as the space for the elaboration of concrete projects and supposes the exercise in capacities to choose between possible and pertinent courses of action for the situation, skills for the selection of methodologies, means and resources, the design of operational work plans and the ability to put them into practice. The seminars and workshops propose problems of teaching different fields of mathematics and take their name from this conceptualization of vocational training:

- Problems of numbers teaching,

- Problems of geometry teaching,

- Professional problems of mathematics teaching at school,

- Workshop on problems related to the transition between teaching levels.

In this way, it could be said that the Diploma as a whole is a teaching experiment and each of the seminars and workshops are other experiments that, taken together, make up the general experiment. This conception of the Diploma generates a possible tension between the so-called teaching experiments and the Didactic Engineering in Mathematics Education (Artigue, 1995) that we will not develop in this article.

\subsection{The preparation of the experiment}

The tasks proposed in the experiment are grouped in the different seminars and workshops, around a mathematical problem that allows various resolution strategies, and then reflect on what has been done within the framework of the subdomains of the MTSK model. Papers like this, based on teaching experiments, require evaluation of participant's outcomes (Cobb et al., 2016). To evaluate the results, we analyze the change in the use of knowledge and the ability to mobilize different categories of it. In this article we share some sessions of the Problems of the Teaching of Geometry Seminar for primary school teachers. The knowledge to be evaluated is focused on some subdomains of MTSK model. Regarding the Knowledge of the Topics, the resolution of the task and the identification of contents was evaluated. In the Knowledge of Mathematical Structure, the relationship with mathematical contents unrelated to the task was evaluated. With regard to the Didactic Knowledge of the Content, the use of resources, theories, and coherence between the proposed tasks were evaluated. As for the Knowledge of the Characteristics of The Learning of Mathematics, we worked on the forms of interaction of possible students with the task. As for the Knowledge of The Learning Standards of Mathematics, we focus on the use of the curriculum and the articulation between the different curricular blocks.

\subsection{Experimentation}

In example 1, we present a session of the work of the Problems of geometry teaching Seminar that allows us to operationalize the categories we described as central of our conceptualization of the specific knowledge of the professional of mathematics teaching. We want to stand out the fact that the Diploma is a virtual course, so the activities are planned according to this organization's modality. 
Example 1: 5th session of the Diploma

Session 5 of the seminar: Problems of geometry teaching

We propose to discuss on the forum the ideas from the following text we have written for this session. Its title is: "At school we teach: space or geometry?"

Some authors consider that spatial knowledge and geometric knowledge have different characteristics. So they claim that:

Students have spatial knowledge long before they learn geometry knowledge. In that knowledge genesis, it turns out that geometry must be taught in order to exist. In the case of spatial knowledge, we can talk about a "natural" genesis and, in the case of geometric knowledge, it is totally "scholastic" (or institutionalized).

Even though there is a large number of common words between the spatial and the geometric, they don't have the same meaning. In ordinary or professional life (outside mathematics) nobody uses geometric vocabulary to denote a square-shaped object as a rectangle; in geometry, on the contrary, to claim that: every square is a rectangle constitutes the demonstration of a particular knowledge, of a geometric proposition that has been a teaching object.

The contents of scholastic geometry programs are organized into conceptual nodes that include figures, regular polygons, the relative position of lines, the study of parallelism and perpendicularity, angle classification, among others. The structure of spatial knowledge is much less known. They are used, normally, to solve very specific situations in different professional fields: carpenter, draftsman, electrician, surveyor, plumber, builder, etc. This conceptual organization of the contents sometimes takes you away from the real problems that you can help to solve.

In spatial problems, we "show" the solution we found and validate its suitability using empirical means. In geometric problems, we appeal to a mathematically approved solution. The nature of knowledge validation in geometry takes us to develop skills for the demonstration.

The concepts highlighted with bold in the previous paragraphs (knowledge genesis, vocabulary, conceptual organization, nature of validation) allow us to make a few questions regarding our profession:

a. At school, do we teach the concepts that every citizen needs to unwind themselves in the space?

b. At school, do we teach geometry to contribute to the development and domain of the students with sensitive space?

c. At school, do we teach geometry just to develop a knowledge learning that is the object of totally formalized cultural knowledge?

d. At school, do the students go "naturally" from a practical and spontaneous relation with space to an activity of geometric modelling?

When we talk about modelling, we do it in two ways: analogic and geometric modelling. Space modelling is called analogic because students put into operation strategies based on the construction of schemes, sketches, drawings, graphs, maps, blueprints, etc., in the resolution processes of problematic situations proposed in the "lived" space. This modelling preserves properties of topological nature: proximity, order, convexity, interior and exterior, frontier, continuity, etc., but doesn't always keep geometric relations such as proportionality, parallelism, perpendicularity, etc. The space modelling is called geometric when students build techniques based on geometry knowledge: angles, straight lines, polygons, transformations (symmetries, rotations, translations...), parallelism, perpendicularity, congruence, similarity..., in the resolution of problematic situations proposed on the "lived" space. It is about a modelling that allows us to establish a relation with space in such a way that the geometrical notions intervene as means of decision, action, or reasoned prevision about a sensitive space. The resolution of spatial problems enables us to generate space modelling practices thought meaningful employment of geometry's objects that make up the curricular design that students have to study at school.

So, we ask ourselves:

e-How does it benefit the learning of geometry, proposing sequences that allow evolving from an analog modelling to a geometrical modelling?

We propose the following Activities to "dialogue" with the text read.

These are activities of personal resolution. Its aim is to be useful to establish a dialogue with the ideas from 
the text. The answers to these questions are, not necessarily in a linear way, in what is stated there and in what each one conceives from the teaching process.

a. Which is the conceptual network that links the highlighted words in the text? Is that network unique?

$b$. What answers can you give to each one of the questions identified in the text with the letters a-e?

c. Why do you think that geometry is a subject that has been chosen to be taught at school?

In the planning of the transcript session of the Diploma, we took into account that its axis was the debate about teaching problems. To do so, we appeal, on each question offered in this session, to certain aspects of what we describe as specialized knowledge of the teacher as a professional of teaching. In Figure 1, we show the association, taking as a reference the scheme that synthesizes the MTSK model to which we refer:

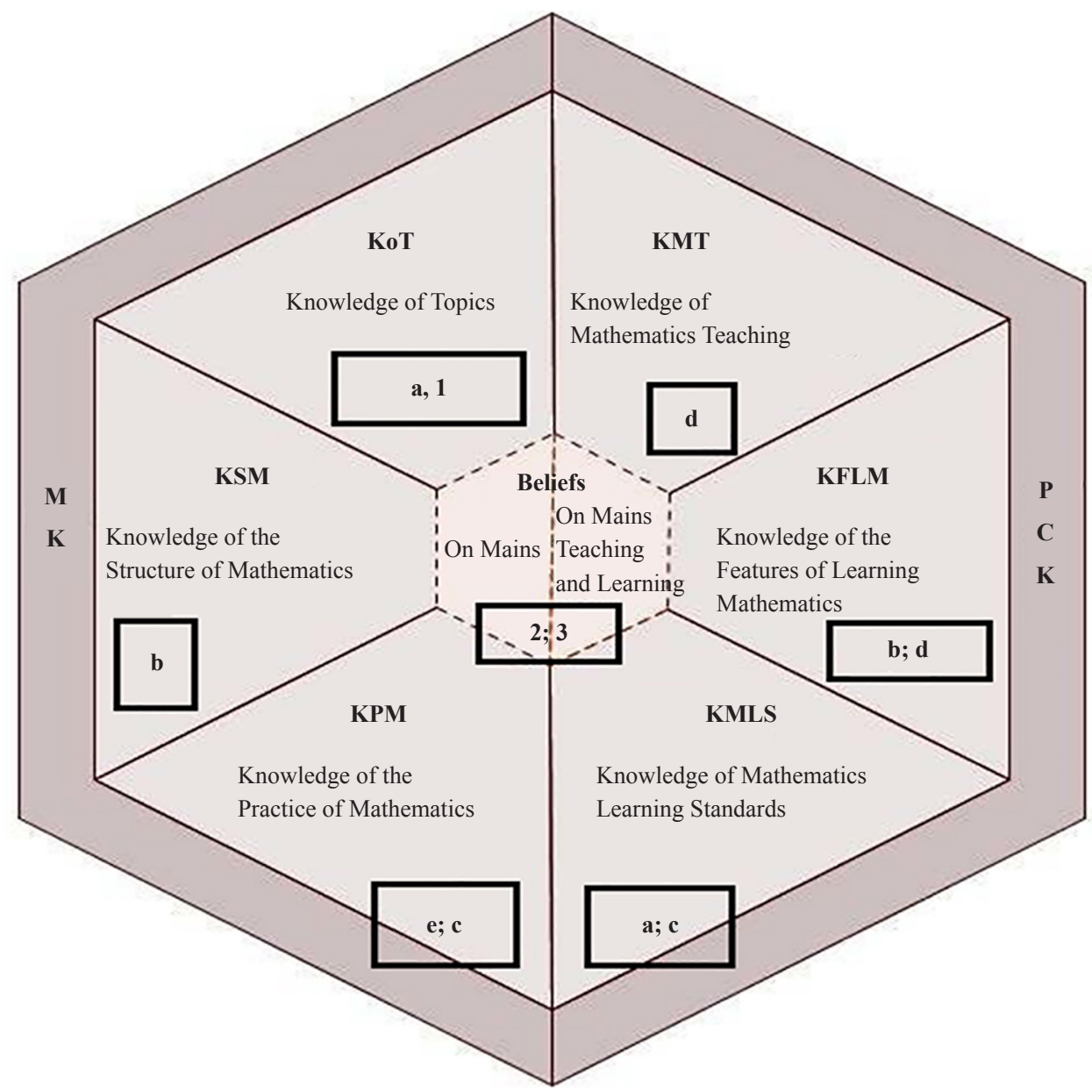

Figure 1. Relation of the session questions with the content of the MTSK model. Source: own elaboration on the original diagram of the MTSK model

\subsection{Retrospective analysis}

In the forum, as a tool of the Moodle classroom where the proposal is supported, there were exchanges with which we can exemplify some of the answers given to the questions and that allow us to show how the planned was developed in the space of the training. Each participating teacher is identified with the code Dn where D differentiates it from the Moderator of the forum (M) and the subscript does so from its colleague. We show it in Example 2. 
Example 2: Transcription from a fragment of the participation in the forum of session 5 of the Diploma

M:-All the words in bold in the text, allow you to ask the a-e questions?

D1:-It seems to me that this is complete. I always thought that geometry and space were the same.

D2:-I didn't even question its use. I always say I work with space, I work with geometry as if saying the same. I questioned everything I had studied when the subject of modelling was raised.

M:-What is your proposal?

D2:-It was just that for me it was natural, as the text says that, if I played in the schoolyard, later I could go to the folder or the notebook and draw. And that was it...

D3:-But to do geometry is more than drawing. Or at least that's what I think. It goes more to the side of measuring, using instruments, complying with certain properties.

D4:-I agree, but when I read the text I understood something else. I understood that you can think about what we did in the schoolyard without drawing, and we are also doing geometry.

M:-Do you all agree?

D5:-I'm still thinking about it. I always liked to use the drawing compass, to measure with the rule, play with the conveyor. Now, with the software that we have available, I like to make the boys and girls explore with the machine. Now I ask them to do their drawings mechanically and I don't go to the schoolyard so often...

D3:-You stopped using the sheet to start using the screen... put the text says something different. It sends us to the schoolyard and from there to the folder. But... when do I ask the students to study the properties? When do they study?

Both M's interventions and Dn's answers generate a useful dialogue about the professional problems to deepen about some aspects of specialized knowledge that start to appear. A decision in M's management made the question e-appear in the dialogue with a supporting feature. We'll show it in the extract we transcribe in Example 3:

Example 3: Fragment of session 5 forum with deliberated intervention from the moderator

M:-Did you think about the answer to question e? Before you say your answers, I propose to analyze this sequence that we found for students from 8 to 9 years old. It is called From Volleyball to the board. It is this one:

1-Draw on the schoolyard or in the classroom (if you have room to do it) a court with these characteristics:

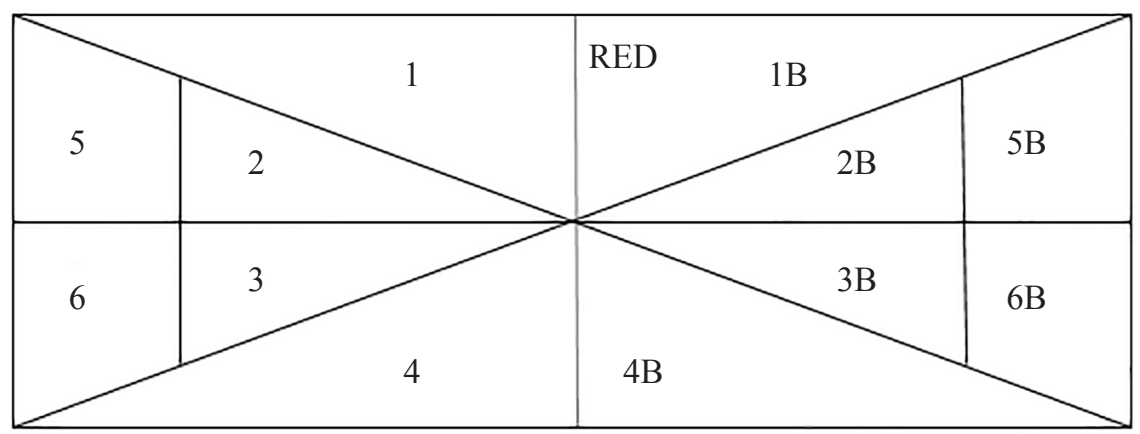

Get a beach ball (light, transparent plastic ones) or a balloon. When you have everything you need, form teams with the same number of participants as the spaces marked on the court. Choose who will be the referee of the game you'll play and how will the scores be registered.

1-With everything settled, you'll play a very special volleyball. It is played two teams at a time. Each team 
places its players in the court's sectors on each side of the net. The rules are simple: you can only throw the ball to the other side of the net once that the team that has it has made three passes among its players. The passes can only be done when the one who's throwing the ball names the player to the one who passes it by his or her location (for example: goes to my right, goes backward...). You get points when the other team loses the ball; when a team does not comply with the rules.

2-Answer after playing:

What can the names of the spaces marked on the court be used for?

What strategy should you use if you want to win the game? Does it always work?

3-Together, chose the play that you think is the most interesting and write it so that everyone has their register. How can you make the drawing reflect so that it stays in the folder or notebook as a picture of your play?

4-Let's use the same court. Take away the net so there won't be any accidents and change the name of the sectors for the numbers you get by adding the value left on the top face of two dices that are rolled. Could you reach the sectors to occupy? Why?

5-Let's make our board more comfortable and change the dividing lines. We show you a possibility, you chose

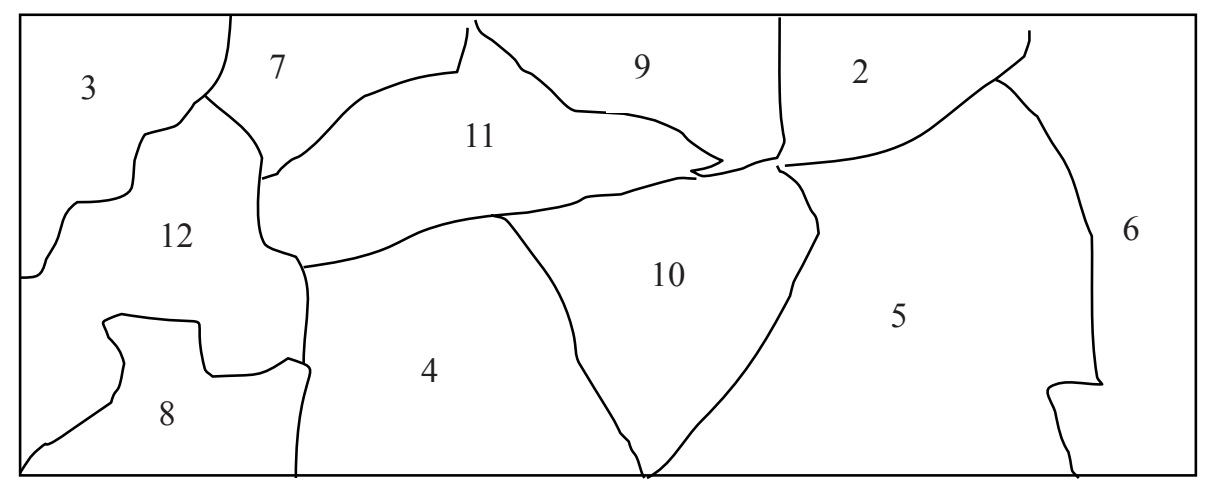

In this case, you have to use your bodies and say out loud what is happening. One of you has to roll the dices and add the value of the top of the faces. Someone else hast to occupy the place on the board that has that number with one part of your body. You keep rolling the dices, adding values and the same players cover the board with his or her body. Rules: you can't change the body part you have already used for another; you can't get help from someone outside the board. The team whose representative has been able to cover as many parts of the board as possible, wins.

1-Answer:

Is there a number on the board that came up more times to be covered?

Which part of the body should you use first to cover the first part? Does it always work?

Does the place where the numbers are located on the board influence the result? Why?

Is there any relation between the player's height and the possibility of winning?

2-Imagine how can you narrate what happened with words and drawings. Do it in your notebook or folder.

M:-What do you think about this sequence?

D6:-It is very good! I want to use it.

M:-That is very flattering, but: how can we be sure that, what you described as good, we all see it the same? I mean: what does it mean to be good?

D6:-It lets us play, have fun at the schoolyard. After that, we can go to the classroom. It's fun, it's dynamic...

M:-And what does it allow us to teach? What would we use it in the classroom for? What do the students learn when they go through it?

D6:-Ge-o-me-try (laughs).

D7:-Ha, ha... but, why? I didn't get it. I don't know why after volleyball it goes to the board with numbers and the dices appear... 
D4:-The difficulty varies and adds new things.

D5:-What for? I would play volleyball and would settle for them to think about the court, draw it, and that's

it.

M:-And you wouldn't ask for that winning play?

D3:-That is interesting. Besides using words from the space (to the right, to the left...) they have to write. We are doing a language with mathematics and physical education. I like that!

D10:-And I liked the thing about the dices. Because there you have the addition, the operations, the possible results... They have to anticipate; they have to...

D11:-Realize that 12 has as many chances to go as 2 and 7 has the most chances.

D14:-It creates a very wide view of the class.

D7:-We do geometry because we are modelling the court and we include arithmetic with the operations, a language with the justifications, and...

The dialogue is more extensive. Our interest with the fragment is to show from the analysis of an activity, how we can explain some professional problems:

- Think if the sequence allows the group of students that are working with the activities to elaborate personal strategies to solve geometrical problems referred to the passage from three to two dimensions,

- Analyze the development level of some of the mathematical contents used to give meaning and significance to the sequence: position and orientation on the plane; position and orientation in space; location in space; the passage from three to two dimensions; conjecture elaboration; ideas communication,

- Discuss the management of didactic variables associated with the modification of the mean offered to students: insertion of problems of the mathematical field to game situations and space modelling with an explanation of arguments,

- Consider which teaching strategies are more efficient to achieve geometrical knowledge,

- Characterize which indicators of performance are the ones that, when we ask the students to work with flat renderings of three-dimensional spaces, allow them to evaluate their learning. We refer to:

- establish, maintain and respect the rules of a game,

- generalize strategies from the comparison of plays and relevant features of the shapes,

- use mathematical vocabulary to communicate mathematical ideas,

- debate about which elements are generalizable and which are not in a specific situation,

- argue about the relevance of the conjectures constructed from the results of the activities.

At the same time, we evidence that the projects to solve these problems lead to the rereading of the curricular design, the revision of our knowledge about the contents, how to plan them to take them to the classroom, how they could be learned, etc.

\section{Conclusions}

We have developed our ideas about the mathematics teacher specialized knowledge and exemplified its construction and analysis from an academic proposal of training at a university level. We understood and justified this idea: the Diploma tries to produce relevant knowledge about professional practice and to find dialogue channels between the socalled research world and the practice world. We believe that in this way we favor a process of knowledge production about mathematics teaching and learning that is carried out jointly between researchers and teachers, who interact to contribute from their specialties to the construction of knowledge. This knowledge emerges from the reflection about the practice of mathematics teaching and comes back to it, to give meaning to the teacher's choices that are taken daily in the process of teaching.

The implementation of this method supposes the development of joint activities between teachers and researchers: interventions in the mathematics that are taught are not only fertile in terms of students learning, but also for the teacher's reflection about how they teach.

We recovered the teacher's voice from the comprehension of their practice, which is produced when it is also 
the producer of the teaching situations that would be object and instrument of study. In these conditions, the teaching scenarios and the activities developed for the classes, appear as a legitimate way of finding a meaning to the experience of teaching: the complexity of the teaching practices allows us to notice the limits and margins that these teachers have of their class, and also the unexpected of students work.

Epistemologically, the construction of knowledge in mathematics didactic starting from our proposal is produced in the real context where the practice of teaching mathematics takes place, assuming that the components of this context are a restructuring object when we assume that teachers are participants of a specific context. This professional competence is referred to the teacher's capacity to exercise his or her critical judgment when they make decisions about their practice, depending on the prevailing conditions and betting in the context of the specific action. This construction of knowledge related to a determined professional practice is founded in the teacher's understanding of the teaching situations in which they develop themselves professionally and assume themselves as professionals who can reflect on them. According to this perspective, our proposal is based on a dialogue with the teachers from the inside of the context in which they work on, to understand how these professionals substantiate their decisions and put them into practice, thus transforming into interpreters (in terms of understanding and explaining) of their actions. In this joint construction, we interact and explore topics of common interest. The Diploma promotes and maintains a kind of conversation between the teacher's practice and the reflection (between moderator teachers), between teaching and didactic: an interpretation area that goes around situations that are the object of our exploration. This reciprocal space of argumentation develops a series of debates about how each one gives meaning in the context of schooling; gives meaning to the co-construction of knowledge and becomes a mediation place between the research culture and the teaching culture. In this way, we believe that specific knowledge is built in the teacher, at the service of informed practice.

\section{References}

Aké, L. P., \& López-Mojica, J. M. (2020). Naturaleza de las tareas profesionales en la formación de profesores de matemáticas [Nature of the Professional Tasks in Mathematics Teacher Training]. Páginas De Educación, 13(1), 58-81. https://doi.org/10.22235/pe.v13i1.1919

Anderson, G. (1970). Effects of classroom social climate on individual learning. American Educational Research Journal, 7(2), 135-152. https://doi.org/10.3102/00028312007002135

Artigue, M. (2004). Ingeniería didáctica en educación matemática. Un esquema ara la investigación y la innovación en la enseñanza y el aprendizaje de las matemáticas [Problems and challenges in mathematics education: what the didactics of mathematics offers us today to face them]. Educación matemática, 16(3), 5-28.

Artigue, M., Douady, R., Moreno, L., \& Gómez, P. (1995). Ingeniería didáctica en educación matemática [Didactic engineering in mathematics education]. Un esquema para la investigación y la innovación en la enseñanza y el aprendizaje de las matemáticas. Una Empresa Docente. Bogotá: Grupo Editorial Iberoamérica.

Ávalos, B. (2007). El desarrollo profesional continuo de los docentes: lo que nos dice la experiencia internacional y de la región latinoamericana [Teacher continuous professional development: what international and Latin American experiences tell us]. Pensamiento Educativo, 41(2), 77-99.

Ball, D. L., Thames, M. H., \& Phelps, G. (2008). Content knowledge for teaching: What makes its special. Journal of Teacher Education, 59(5), 389-407. https://doi.org/10.1177/0022487108324554

Ball, D. L., Rowland, T., \& Davis, B. (2009). Teacher knowledge and teaching: viewing a complex relationship from three perspectives. In M. Tzekaki, M. Kaldrimidou, \& H. Sakonidis (Eds.), Proceedings of the 33rd Conference of the International Group for the Psychology of Mathematics Education1 (pp. 121-150). Tesalónica, Grecia: PME.

Bell, C., Wilson, S., Higgins, T., \& McCoach, D. (2010). Measuring the effects of professional development on teacher knowledge: The case of developing mathematical ideas. Journal for Research in Mathematics Education, 41(5), 479-512.

Bullough, R. (2000). Convertirse en profesor: la persona y la localización social de la formación del profesorado [Becoming a teacher: the person and the social location of teacher training]. In B. Biddle, T. Good, \& I. Goodson (Eds.), La enseñanza y los profesores, I La profesión de enseñar. Barcelona: Paidós.

Carrillo, J., \& Climent, N. (2011). The development of teachers' expertise through their analyses of good practice in the mathematics classroom. ZDM Mathematics Education, 43(6-7), 915-926. https://doi.org/10.1007/s11858-0110363-0

Carrillo, J., Climent, N., Contreras L. C., \& Muñoz-Catalán, M. C. (2013). Determining specialised knowledge for 
mathematics teaching. In B. Ubuz, C. Haser, \& M. A. Mariotti (Eds.), Proceedings of the VIII congress of the European society for research in mathematics education (CERME 8) (pp. 2985-2994). Antalya, Turkey: Middle East Technical University, Ankara.

Carrillo, J., Climent, N., Montes, M., Contreras, L. C., Flores-Medrano, E., Escudero-Ávila, D., Vasco, D., Rojas, N., Flores, P., Aguilar-González, A., Ribeiro, M., \& Muñoz-Catalán, M. C. (2018). The Mathematics Teacher's Specialised Knowledge (MTSK) model. Research in Mathematics Education, 20(3), 236-253. https://doi.org/10.10 80/14794802.2018.1479981

Carrillo, J., Climent, N., Contreras, L. C., \& Montes, M. (2020). Using professional development contexts to structure prospective teacher education. In S. Llinares, \& O. Chapman (Eds.), International Handbook of Mathematics Teacher Education (pp. 393-419). Londres: Brill.

Climent, N. (2005). El desarrollo profesional del maestro de Primaria respecto de la enseñanza de la matemática [The professional development of the Primary teacher in the teaching of mathematics. A case study]. Un estudio de caso. Michigan: Proquest MichiganUniversity.

Cobb, P., \& McClain, K. (2001). An approach for supporting teachers' learning in social context. In F. L. Lin, \& T. J. Cooney (Eds.), Making sense of mathematics teacher education (pp. 207-231). Dordrecht: Kluwer.

Cobb, P., Jackson, K., \& Dunlap, C. (2016). Design research. An analysis and critique. In L. D. English, \& D. Kirshner (Eds.), Handbook of International Research in Mathematics Education (pp.481-503). Londres: Rouletdge.

Cochran-Smith, M., \& Lytle, S. (2003). Más allá de la certidumbre: adoptar una actitud indagadora sobre la práctica [Beyond certainty: adopting an inquisitive attitude about the practice]. In A. Lieberman, \& L. Miller (Eds.), La indagación como base de la formación del profesorado y la mejora de la educación. Barcelona: Octaedro.

Kaiser, G., \& Li, Y. (2011). Reflections and future prospects. In Y. Li, \& G. Kaiser (Eds.), Expertise in mathematics instruction. An international perspective (pp. 343-353). New York: Springer.

Kuzniak, A. (2011). L'espace de travail mathématique et ses genèses [The Mathematical Work Space and its Geneses]. Annales de didactique et des sciences cognitives, 16, 75-96.

Lin, F. L., \& Rowland, T. (2016). Pre-service and in-service mathematics teachers' knowledge and professional development. In Á. Gutiérrez, G. C. Leder, \& P. Boero (Eds.), The Second Handbook of Research on the Psychology of Mathematics Education (pp. 483-519). Boston: Sense Publishers.

Ma, L. (1999). Knowing and teaching elementary mathematics. Teachers' understanding of Fundamental Mathematics in China and the United States. Mahwah, New Jersey: Lawrence Erlbaum Associates.

Mason, J. (2002). Researching your own practice. The discipline of noticing. London: Routledge Falmer.

Molina, M., Castro, E., Molina, J. L., \& Castro, E. (2011). Un acercamiento a la investigación de diseño a través de los experimentos de enseñanza [An Approach to Design Research through Teaching Experiments]. Enseñanza de las Ciencias, 29(1), 75-88.

Montes, M. A., Contreras, L. C., \& Carrillo., J. (2013). Conocimiento del profesor de matemáticas: Enfoques del MKT y del MTSK. In A. Berciano, G. Gutiérrez, A.Estepa, \& N. Climent (Eds.), Investigación en Educación Matemática XVII (pp. 403-410). Bilbao: SEIEM.

OECD. (2005). Teachers matter: attracting, developing and retaining effective teachers. París.

OREALC. (2013). Antecedentes y Criterios para la Elaboración de Politicas Docentes en América Latina y el Caribe [Background and criteria for teacher-policy development in Latin America and the Caribbean]. Santiago, Chile.

Putnam, R., \& Borko, H. (2000). El aprendizaje del profesor: implicaciones de las nuevas perspectivas de la cognición [Teacher learning: implications of new perspectives on cognition]. In B. Biddle, T. Good, \& I. Goodson (Eds.), La enseñanza y los profesores, I La profesión de enseñar. Barcelona: Paidós.

Reyes-Gasperini, D., \& Cantoral, R. (2013). Socioepistemología y Empoderamiento: la profesionalización docente desde la problematización del saber matemático [Socioepistemology and Empowerment: teacher professionalization from problematization of mathematical knowledge]. Boletim de Educação Matemática, 28(48), 360-382.

Rhoads, K., Radu, I., \& Weber, K. (2011). The teacher internship experiences of prospective high school mathematics teachers. International Journal of Science and Mathematics Education, 9, 999-1022.

Rowland, T., \& Turner, F. (2009). How shall we talk about 'subject knowledge' for mathematics teaching? In M. Joubert (Ed.), Actas de la Sociedad Británica de Investigación en el Aprendizaje de las Matemáticas (pp. 1-20). Universidad de Southampton, Reino Unido.

Sánchez-Matamoros, G., Fernández, C., \& Llinares, S. (2015). Developing pre-service teachers' noticing of students' understanding of the derivative concept. International Journal of Science and Mathematics Education, 13(6), 1305-1329.

Sanhueza, S., Penalva, M., \& Friz, M. (2013). Identidades y competencias profesionales de estudiantes para maestro de educación infantil relativas a la enseñanza de la geometría [Identities and competences of kindergarten teachers 
students for the teaching of geometry]. Revista Latinoamericana de Investigación en Matemática Educativa, 16(1), 99-125.

Shulman, L. S. (1986). Those who understand: Knowledge growth in teaching. Educational Researcher, 15(2), 4-14.

Skovsmose, O. (1999). Hacia una filosofía de la Educación Matemática Crítica [Towards a philosophy of Critical Mathematics Education]. Bogotá.

Steffe, L. P., \& Thompson, P. W. (2000). Teaching experiment methodology: Underlying principles and essential elements. In R. Lesh, \& A. E. Kelly (Eds.), Research design in mathematics and science education (pp. 267-307). Hillsdale, $\mathrm{N}$ J: Erlbaum.

Vezub, L. (2013). Hacia una pedagogía del Desarrollo profesional Docente. Modelos de formación continua y necesidades formativas de los profesores. Revista Páginas de Educación, 6(1), 97-124. http://paginasdeeducacion. ucu.edu.uy/inicio/item/43-pags_edu6.html

Vezub, L. (2018). Políticas de desarrollo profesional de la docencia: la formación continua [Teaching professional development policies: continuous training]. Módulo del Programa de Formación en Políticas Docentes. IIPEUNESCO Buenos Aires.

Vezub, L. (2019). Las políticas de formación docente continua en América Latina [Continuing teacher training policies in Latin America]. Mapeo exploratorio en 13 países. UNESCO-IIEP. Buenos Aires.

Villella, J., Fioriti, G., Ferragina, R., Lupinacci, L., Bifano, F., \& Almirón, A. (2018a). A professional development experience in Geometry for High School teachers: introducing teachers to Geometry workspaces. In P. Herbst, U. Cheah, K. Jones, \& P. Richard (Eds.), International Perspectives on the teaching and learning of Geometry in secondary schools (pp. 197-214). Cham: Springer.

Villella, J., Fioriti, G., Ferragina, R., Lupinacci, L., Bifano, F., Güerci, V., Amman, S., \& Almirón, A. (2018b). Puentes pedagógicos. Hacia una definición de intervención en la práctica de aula [Pedagogical bridges. Towards a definition of intervention in classroom practice]. In S. Muiños de Britos (Ed.), Redes, puentes y vínculos entre la universidad y las escuelas secundarias (pp. 69-102). Buenos Aires: UNSAM edita.

Wu, H. H. (2018). The content knowledge mathematics teachers need. In Y. Li, W. J. Lewis, \& J. J. Madden (Eds.), Mathematics Matters in Education (pp. 43-91). Springer. 